\title{
MONITORING CITIES OF TOMORROW, MEETING OF URBAN COMMISSION C I 9 INTERNATIONAL GEOGRAPHICAL UNION
}

Oddelku za geografijo Filozofske fakultete je po večletnih prizadevanjih uspelo pridobiti organizacijo Znanstvenega seminarja Komisije za urbano geografijo Mednarodne geografske zveze. Eden največjih geografskih mednarodnih znanstvenih sestankov pri nas z delovnim naslovom "Cities in transition" je bil na Filozofski fakulteti v Ljubljani od 17. do 24. avgusta 2003. Seminarja se je udeležilo okrog 60 tujih strokovnjakov iz 24 držav, največ iz Japonske, Nemčije, Izraela, Kanade, Španije in Francije. Veliko zanimanje so pokazali tudi slovenski geografi in drugi strokovnjaki s področja proučevanja urbanega prostora, ki so aktivno sodelovali v zanimivih razpravah. Nenavadno veliko zanimanje je bilo tudi s strani časopisov (Delo, Slovenske Novice, Večer, Ptujski tednik), ki so objavili pogovore s svetovno znanimi strokovnjaki z željo posredovati bralcem njihovo videnje nadaljnjega razvoja urbanizacije, mestnih naselij in še posebej velikih mest, katerim je, tudi zaradi porekla referentov, veljalo največ zanimanja. RTV Slovenija je v Odmevih seminarju odmerila posebno pozornost.

Blizu šestdeset referatov je bilo razdeljenih v šestnajst sekcij v okviru naslednjih osnovnih tematskih sklopov: New theoretical perspectives, Cities in transition, Cities in transition -Case studies, Cities and economic change, Urban system, Neighbourhoods, Segregation and diferentation, Urban growth and renewal, Urban region and suburbanisation, Natural environment and sustainable develompent. Razvojno problematiko slovenskih mest je predstavilo sedem slovenskih geografov (A. Černe, V. Drozg, M. Krevs, S. Kušar, M. Pak, D. Rebernik, M. Špes).

Na strokovni ekskurziji so si udeleženci ogledali Ljubljano in spoznali na Oddelku za urbanizem MOL njeno razvojno problematiko. Enodnevna ekskurzija je bila namenjena spoznavanju predalpske in subpanonske Slovenije z obiski Velenja, Maribora in Ptuja. Zaključna dvodnevna ekskurzija pa je udeležence vodila po Gorenjski, preko Vršiča v Posočje (Nova Gorica), in čez Kras v Slovensko Primorje (Koper, Izola, Piran, Portorož).

Raznolikost, majhnost, prehodnost ter obmejnost Slovenije so tuje strokovnjake, med katerimi jih velik del Slovenije še ni poznal, nekateri pa so bili celo prvič v Evropi, izredno navdušili. Ni bilo redkih pisnih komplimentov za odlično organizacijo, lepoti Slovenije in želja po ponovnem obisku. Organizacija tako velikega in zahtevnega strokovnega sestanka, ki sta mu vseskozi stala ob strani predsednik Komisije prof.dr. Gerhardt Braun in njen tajnik prof.dr. Vim Ostendorf, je bila mogoča le ob izredni požrtvovalnosti članov Organizacijskega odbora, ki jim velja vsa zahvala. Zahvala pa velja tudi vsem drugim, ki so izvedbo simpozija omogočili : Filozofski fakulteti Univerze v Ljubljani, Ministrstvu za šolstvo, znanost in šport RS, Mestni občini Ptuj, Vinarskemu podjetju Slovenske gorice - Haloze na Ptuju in Oddelku za geografijo Filozofske fakultete.

Mirko Pak 